\title{
Intake and digestibility of hay supplemented with Chamaecytisus palmensis (tree lucerne) by sheep
}

\author{
WA van Niekerk, HH Meissner, NFG Rethman
}

University of Pretoria, Pretoria, South Africa

Tree lucerne or Tagasaste, is a leguminous shrub which grows in a wide variety of climatic conditions. Native rangeland in the drier summer rainfall areas of South Africa, may limit animal production due to suboptimal intake which resolves from high cell wall and/or low nitrogen contents of available forage.

The object of this study was to compare the effect of Tagasaste supplementation on intake and digestibility of good, medium and low quality hay.

The study was conducted in an area with an exclusively summer rainfall of $650 \mathrm{~mm}$ per annum, dry autumn and winter. Eragrostis curvula hay of three different qualities were used : low (L) $(0.77 \% N)$, medium (M) $(1.16 \% N)$ and high $(H)(1.79 \% N)$. The hay was fed alone or supplemented with $190 \mathrm{~g}$ dried Tagasaste $(2.39 \% N)$ to sheep in metabolism cages. The sheep were fitted with faecal bags together with rumen, abomasal and ileal cannulae. Partial digestion of organic matter and disappearance of non ammonia-N (NAN) in the small intestine were determined by digesta flow measurement, using $\mathrm{Yb}$-acetate and Cr-EDTA as particulate and fluid markers respectively (Siddons et al, 1985, Br J Nutr, 54, 509-519), and reconstitution according to Faichney (1980, $J$ Agric Sci, 94, 313-318). Markers were continuously infused by a peristaltic pump. Tukey's studentized range test for factorial designs was used to test for differences between forages with or without supplementation.

Both the organic matter intake and digestibility were increased significantly with supplementation of the $L$ and $M$ quality hays (See table). The increase in total OM digestibility as well as OM digested in the stomachs and in the small intestine, were most probably due to an enhanced rumen fermentation as judged by the higher rumen $\mathrm{NH}_{3}-\mathrm{N}$ and volatile fatty acid concentrations. The lower NAN flow at the abomasum of the $L$ group has probably been caused by a lower microbial production rate due to a lower rumen- $\mathrm{NH}_{3}$ concentration (Satter and Roffler, 1975, J Dairy Sci, 58, 1219-1237). The lower faecal ADIN to feed N ratio of the supplemented treatments indicates to an improved protein digestibility. These effects together with more NAN available in the lower digestive tract, could have been responsible for the higher OM intake of the supplemented groups.

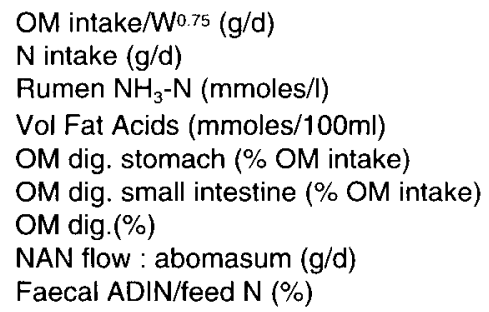

$\begin{array}{ccccccc}H_{+} & H_{-} & M+ & M- & L+ & L- & S e_{m} \\ 78^{a} & 73^{a} & 76^{a} & 59^{b} & 61^{b} & 51^{c} & 3.0 \\ 21^{\mathrm{a}} & 17^{\mathrm{b}} & 16^{\mathrm{b}} & 9.0^{\mathrm{c}} & 12^{\mathrm{d}} & 6.0^{\mathrm{e}} & 0.9 \\ 11^{\mathrm{a}} & 15^{\mathrm{ab}} & 8.0^{\mathrm{bc}} & 7.0^{\mathrm{cd}} & 64^{\mathrm{d}} & 3.6^{\mathrm{e}} & 0.8 \\ 21^{\mathrm{a}} & 19^{\mathrm{ab}} & 18^{\mathrm{ab}} & 17^{\mathrm{ab}} & 17^{\mathrm{ab}} & 16^{\mathrm{b}} & 2.1 \\ 47^{\mathrm{a}} & 43^{\mathrm{ab}} & 47^{\mathrm{a}} & 42^{\mathrm{b}} & 45^{\mathrm{ab}} & 40^{\mathrm{b}} & 2.4 \\ 12^{\mathrm{a}} & 8^{\mathrm{b}} & 11^{\mathrm{a}} & 6^{\mathrm{b}} & 9^{\mathrm{a}} & 5^{\mathrm{b}} & 1.3 \\ 65^{\mathrm{a}} & 54^{\mathrm{b}} & 62^{\mathrm{a}} & 52^{\mathrm{b}} & 58^{\mathrm{a}} & 50^{\mathrm{b}} & 2.9 \\ 20^{\mathrm{a}} & 20^{\mathrm{a}} & 17^{\mathrm{b}} & 13^{\mathrm{c}} & 13^{\mathrm{c}} & 8.0^{\mathrm{d}} & 1.1 \\ 14^{\mathrm{a}} & 21^{\mathrm{b}} & 24 \mathrm{bc} & 41^{\mathrm{d}} & 27^{\mathrm{c}} & 50^{\mathrm{e}} & 2.4\end{array}$

